\title{
Japanese Education and Japanese Elementary School
}

\author{
Abdul Aziz \\ Staf Pengajar pada PGMI Fakultas Tarbiyah UIN Malang
}

\begin{abstract}
Pendidikan merupakan jantung kehidupan bagi masyarakat Jepang. Sebagai negara yang miskin sumber daya alam serta rawan bencana alam, bangsa Jepang sangat menggantungkan kepada proses pendidikan dalam memberdayakan sumber daya manusianya untuk mempertahankan kelangsungan hidup bangsa serta bersaing dengan bangsa-bangsa lain di dunia dalam bidang politik, ekonomi, teknologi dan lain-lain. Dibandingkan dengan negara-negara lain terutama dari kelompok G8(kelompok Negaranegara industri maju di dunia,) Jepang mempunyai sistem pendidikan yang unik. Kalau negara industri maju lainnya menitik beratkan dalam pengembangan intelegensi tapi Jepang lebih memberdayakan mental untuk bekerja keras, bergotong royong dan kesetia kawanan sosial, dan pantang menyerah dalam menghadapi setiap permasalahan. Pendidikan Jepang pada awalnya banyak dipengaruhi oleh Cina, namun dalam iperkembangan selanjutnya Jepang juga mengadopsi sistem pendidikan barat dengan tetap mempertahankan ruh pendidikan Jepang sendiri yakni sikap mental pantang menyerah dan menjunjung tinggi gotong royong sesama bangsa Jepang sendiri. Sekolah dasar di Jepang mengutamakan pembentukan sikap dan mental di awal-awal tahun mulai kelas satu sampai kelas tiga kemudian mulai memfokuskan pengkajian ilmu pengetahuan mulai kelas empat sekolah dasar dan seterusnya. Matematika, ilmu pengetahuan(Sain), dan teknologi merupakan aspek penting dalam kurikulum pendidikan di Jepang dalam pembentukan pola pikir yang logis, sistematis dan prosedural bagi bangsa Jepang. Mulai tahun 2002, pelajaran bahasa Inggris resmi masuk dalam kurikulum sekolah dasar di Jepang.
\end{abstract}

Keyword: Japanese education, elementary school curriculum, English subject

\section{A. Background of Study}

Japanese Ministry of Education (Monbukagakusho) defines education as a task to help children develop their own identities and faculties from early childhood to adolescence and is just not school's responsibility. Moskowitz says that a principal purpose of education is to provide learning and an environment that facilitate the achievement of the full potential of the student(Katayama et al,1985).

Japan has long historical background in education. Education is crucial for Japanese society and gives invaluable contribution to the 
modernization and economic affluence of the country. Modern education system began following Meiji restoration. Japan adapted education system to that of western countries. Meiji restoration is the biggest momentum for Japanese society to modernize the country through education.

Japanese education grows very fast after the commencement of Constitution 1947. The constitution states that every Japanese citizen has equal opportunity to education and has to attend the compulsory education for nine years. According to the constitution, the goal of education is to develop healthy spirit and body of Japanese people who are filled with an independent spirit, respect the value of individuals, and love truth and justice.

The participation number of children for education is very high in Japan. $97 \%$ of Junior High School students go to Senior High School and around $50 \%$ of Senior High School graduate continues to university level. The Japanese students are very superior in cross national study of academic achievement especially in Math and basic science.

Japan always develops and designs curriculum to adjust education process to the advance of science and technology, rapid growth of economy, and global era of society. It is very important to keep Japan on the right track to compete with other nations in the era of high competition. Japan introduces new curriculum for Japanese schools beginning 2002 and it is called curriculum 1998. Curriculum 1998 introduces a period of integrated study as an important new feature in Japanese education. According to curriculum 1998, school is the place to transfer the culture to the children. The school has to promote mutual understanding and better relationship among school members, nature and other people. The school has to improve teaching process that allows the learners understand their potential, clearly define their own future objectives, and learn how to learn. Curriculum 1998 encourages the students to design their own curriculum, find their own goal and take necessary steps, and do learning process at their own pace. Curriculum 1998 is basically school based curriculum since the school is free to design the curriculum allowing for school characteristics, students' background, and the expectation of society. English is introduced to elementary school students as English activity in curriculum 1998. It is intended to improve creativity, thinking skill, and deepen understanding of way of life and culture of Japanese and the rest of the world, and promote international understanding among Japanese students from the early time of their education activity.

It is very important to study the education system of another country to get the comparative data as a parameter to improve our national education standard. From the available data, we understand very well our position in the global competition and what we should do to compete with other countries in the field of education. We use the reliable data as a 
guidance to develop education process and we do not use an anecdotal issue to improve our national education standard.

\section{B. Japanese Education}

Like other industrialized countries, education is the central of life in Japanese society. Education is the soul for Japan, and it is the spirit to live for Japanese. Education plays a decisive role to cultivate human capital as the main asset of Japan to reach high economic standard, advance technology and create better prosperity of society across the country.

Japanese education rooted in long historical development of Japanese society longtime before Edo period. At that time, education took place in the noble family to prepare its descendants to secure the future nobility. They are taught in reading, writing, literary works, and martial arts. There is a school for commoners called 'Terakoya' or village school, this school operates in the temple and the private houses of village. The students of village school learn reading and writing. Buddhist priests are the pioneer of Japanese education, they open the mind of Japanese to know the world life through education.

The most influential country for Japanese education is China. The relation with China marks the beginning of formal education in Japan. Some scholars considers formal education as the teaching of reading and writing to students to achieve literacy level. Literacy level for Japanese began with the introduction of Chinese characters to students of old Japanese schools. Even, Japan derives evaluation system from China, it is popularly called 'keju'. It is demerit system to select the candidates for bureaucrats based on the capability and allocates them in the right position. A good bureaucrat comes from the capability not the nobility. To secure the survival of Japan as a vulnerable country, Japan needs good bureaucrat and technocrat.

Japanese education promotes egalitarian social change by decreasing the impact of social background or family class on academic and socio economic achievement(Cummings,1980). Everyone is equal to get promotion in the social life based on academic achievement, and fair competition in Japanese society encourages all Japanese students to do the best in the study in order to get better future promotion. Japanese Students are very superior in cross-national studies of academic achievement especially in Math and basic science(Stevenson,1991).

Japanese education not only cultivates the mind of students but also develops the students as the whole person. Intelligence is not the only means to create qualified and well developed person. Japan is very concerned with the nurturing of heart and spirit of Japanese student. The strong will of Japanese students to cooperate each other is the key for the future of Japan. Solidarity, commitment, mutual understanding and strong 
cooperation are the matter of life and death for Japan as a vulnerable country.

Among G8 members (top eight industrialized countries), Japan has her own characteristics to manage education system. Most of the developed countries give much priority to the ability(intelligence, talent) but Japanese education promotes 'ganbaru' or the will to endure in any situation during the learning activity(John Singleton,1993). Cumming says that an approach of Japanese education is to develop the students with pure and rich heart, to build up strong and healthy bodies, to promote the spirit of curiosity and intellectual achievement, to encourage the will to endure in any situation, and to help the students understand themselves(Stevenson,1991).

Japanese education especially Japanese school is peculiar to the school system of other countries, and Japanese people are very concerned with educational activity of their children. Cummings(1980) describes the characteristics of Japanese school as follows:

a. Japanese people are very concerned with education.

Japanese people are very supportive to education activity. They make fund raising to support school's finance, provide information for academic improvement, join with the school committee to decide school programs within the academic year, even control educational quality. 'Educational Mom' or 'Kyouiku Mom' is very popular in Japan(Stevenson,1991). Japanese mother is very critical of the education quality provided to her children.

b. Japanese school is inexpensive.

Japanese education costs less comparing to high standard of education and better achievement by the school. The advancement of knowledge and technology is the proof of creativity and productivity of Japanese school.

c. Japanese school is equal.

Japanese school is open to all Japanese children and the central government gives support to reduce inequalities in educational expenditures per student.

d. Japanese school is demanding.

The curriculum covers wide range of subjects and pursues these in great depth. Japanese school gives more time allocation of subjects than that of other countries. Japanese students spend longer time to study the materials.

e. The school is educational unit.

In kindergarten and early years of elementary, learning activity is to prepare the children for schooling. Learning is fun and to encourage the children to be happy with the school is very important. Japanese school 
starts cultivating the mind and developing intellectual capacity of children in the late years of elementary school.

f. Japanese teacher is secure.

Teacher's union is established in Japan to back up teachers to have the rights fulfilled. Japanese teachers have good salary, freedom to express opinion, and are able to continue for further study.

g. Japanese teachers are conscientious.

Japanese teachers are aware of what happens in educational process and what they should do to improve educational quality. They hold seminar on education, educational meeting with PTA(parent teacher association) and local board of education, communicate with parents about learning activity, and do research on education.

h. Japanese teachers believe in whole-person education.

Children are basically good. Japanese teachers believe their important task is to nurture students' hearts, motivates the students, arouse their spirit, and develop well rounded person. Intelligence is important but to be humane is more important.

i. Japanese school is equitable.

Very few Japanese teachers show favoritism to their best student, nor do they denigrate the performance of weak learner. Japanese teachers instill persistence, egalitarian, and solidarity in their students.

Aside from that, school has multi functions and roles in Japanese education. Okano and Tsuchiya(1999) define school's roles as follows:

a. Transmission of knowledge

School is the place to cultivate the mind, transfer knowledge, and develop the intellect capacity of Japanese. Knowledge is transferred to the learners and developed through research and study within the school.

b. Socialization and acculturation

School is the place to socialize and acculturate Japanese children for the adult Japanese world. Japanese children acquire and learn cultural norms, values, and how to behave properly within the school.

c. Selection and differentiation

School selects the people and allocates them in the right position based on the specialty. School identifies the learners' talent as scientist, technician, businessman, and so forth.

d. Legitimation of knowledge

School verifies scientific principles to advance science and technology. The rapid growth of Japanese industry comes from the positive contribution of Japanese school. Japanese school and university never 
stop doing experiments to advance science and technology for the economic affluence of Japan.

Further, Rohlen and Kondo describe that personal character building is significant in child rearing of Japanese society(Stevenson et al,1986). Personal character is shaped by various mental elements such as ki, kokoro, tamashii, and seishin. Ki refers to basic life force that gives person the vitality to live. Kokoro is related to sympathetic and empathetic. Tamashii is elan vital including determination to overcome all odds. Seishin is translated as spirit, a mental attitude that helps a person to tackle a task. To achieve full personal character, children should experience hardship(kuro), endurance(gaman, ganbaru), and the self utmost exertion(ishokenmei). The public and Japanese government are very concerned with personal character building and moral education as the basis of national education. John Singleton(1983) says that the formal curriculum is only the means other goals and the real content of any education process is seishin(individual spirit and character development), shudan ishiki(group consciousness and belongingness), and dantai ishiki(organizational consciousness).

Japanese education progresses in line with the dynamic development of Japanese economy and socio political structure(Shimahara,1986). It is by no means to show that Japanese education changes following where the wind blows. It just shows that Japanese education is flexible to adapt to the social development and the advancement of technology. Japan combines her original culture with the experience of international cooperation to reform Japanese education. As is described before that the beginning of Japanese education reform happened when Japan built relationship with China. It is marked by the introduction of Chinese characters in reading and writing. Learning activity in this era concentrated on the teaching of harmonious life based on Confucian values and loyalty to the nation. English came to Japan together with the coming of western people to Japan(Watanabe and Sasahara,2002). William Adams came to Kyushu and introduced English to Japanese in 1600. The introduction of English to Japanese enriches the cultural property of Japan. Japanese becomes literate with Roman letters and know the culture other than the cultures of far eastern Asian countries.

Education reform of modern Japan era began in 1871 when the Japanese Ministry of Education was established. It was at the beginning era of Meiji restoration. Education has played a central role to build a modern, democratic, and civilized state since this era. The government determined the education order of 1872 to define educational goals of Japan. The order covers some points as follows: 
a. Education is the main means of advancement in life.

b. School's function is to produce independent, moral, and patriotic individual.

c. School must be made for all.

d. All Japanese must study practical arts and science that will benefit society and build modern state.

The order is in line with the opinion of Mori Arinori, the first Japanese Minister of education. He managed the educational plan of Japan together with the prominent American educationists. According to him, education should contribute to the prosperity of Japan, agricultural and industrial interests, Japan's commerce, socio-cultural of Japan, laws and government administration of Japan(Herbert Passin,1965). The Meiji restoration pushed the improvement of national education standard and the increase of economic affluence in Japan. In the early of the twentieth century almost $100 \%$ of Japanese children participated in the compulsory education. The economic miracle in 1960s is the evidence of Japan's success to modernize the country through the establishment of well managed and modern education system. Japan is the first non western country that successfully modernizes education system to move from pre-industrial and agrarian country to modern, democratic, and industrial country(ibid,1965).

The education reform in the twentieth century was decided in 1947. It is aimed at eliminating multi tracks system during the Meiji period. The reform introduces 6-3-3-4 educational period. The students study for six years in elementary school, three years in junior high school, three years in senior high school and four years of undergraduate program in university level. The reform promotes coeducational program and establishes compulsory education for nine years.

The latest education reform is in 1998. Some concerned problems underlie 1998 curriculum reform in Japan, they are as follows:

a. Considerable number of students do not fully understand class content.

b. Children's abilities to independently research, judge and express themselves have not yet fully developed.

c. Children's abilities to view things from different angles are not yet satisfactory.

d. Children are not highly motivated to study.

The idea of integrated study is introduced as the core of 1998 curriculum reform in Japan. The integrated study facilitates the learners to design the curriculum according to their future goals, determine the goals of study and take necessary steps to achieve the goals, and fix learning activity based on their physical and mental development. The purposes of 1998 education reform are as follows: 
a. To help children cultivate rich humanity, sociality, and identity as Japanese living in the international community.

b. To help children develop ability to learn and think independently.

c. To help children acquire basic abilities and skills and grow their own individuality with plenty of scope for educational activities.

d. To encourage individual schools to show ingenuity in developing unique educational activities to make the school distinctive.

\section{Japanese Elementary School}

The goals of Japanese elementary school are as follows:

a. To help the children acquire basic knowledge, skills, and mind to have healthy social life as an individual as well as a member of society or nation.

b. To help the children develop rich humanity, recognize their own charm and individuality through interaction with others and foster mind of self-reliance.

Merry I. White(1989) says that self reliance means the development of oneself with a set of independent motivations and is intended to achieve a capacity for self motivated effort. Further, she states that the pedagogy of Japanese elementary school is based on the idea that all Japanese children are equal in potential and the excitement of learning can be best produced in a unity of equals. It does not mean that Japanese students are homogeneous, but every Japanese student is the best in his specialty and has to do the best in the learning process. Japanese teachers are very supportive to their students and treat them according to their special talent. The school day is to keep harmony and unity among the students. The students play, study, and share the idea with friends in a unified group. They have to do the best in the harmonious and unified circumstance. It is obvious that Japanese elementary school is significant to educate the children to be moral, creative, independent and loyal individuals for the meaningful future life.

Rohlen and Bjork(1998) say that creativity is intensified and promoted in Japanese elementary school. Creativity is related to the original and useful idea, self-expression, diversity, and achievement. Less restrictive parenting of Japanese early child rearing arouses creativity among Japanese children. Japanese elementary school concentrates on training basic skills to the students for both academic and non academic subjects, and it can promote the students' creativity. Self-expression is highly intensified in the early education of Japan. And elementary school environment in Japan is very supportive to the divergent thoughts or ideas of students.

Integrated learning approach is used to transfer the knowledge to the elementary school students in Japan(Merry I. White,1989). The teacher 
describes the topic of learning material from many different angles and relates the topic to multidisciplinary subjects. When the teacher teaches about fish; he can teach biology, geography, and language. For example he teaches life cycle of fish, the area where fish live, and he can ask the students to write a composition about fish.

The school subject of Japanese elementary school by 1940 covered five core subjects: ethics, Japanese language, arithmetic, music and physical education. Under the 1947 fundamental law of education, school subjects include Japanese language, social studies, arithmetic, science, music, art and handicraft, home making, and physical education. According to curriculum 1998, school subjects of elementary school are as follows:

\section{a. Dotoku(Moral Education)}

This subject is intended to educate the students to acquire values and norms, behave properly according to the situation and condition, be respectful to others, and obey the norms and positive laws. This subject includes moral values, social relationship, fellowship, peaceful social order, encouraged life, cultural norms, and positive laws.

b. Kokugo(National Language)

This subject is aimed at educating the students to use the language elements properly to express the idea, give critical opinion to others, understand others' opinion in communication activity, and advance science and technology. National Language includes listening, speaking, reading, and writing. Hiragana, Katakana, and Chinese characters(Kanji) are the fundamental of written language in Japanese.

c. Sansu(Math)

It is intended to promote counting ability, data analysis using Mathematical approach, and instill Mathematical basis relevant to everyday life in the students. Math includes numeration, geometry, and data analysis.

d. Rika(science)

The aims of Science subject are to promote students' interest on the environmental issue and how to conserve it, to understand the natural phenomenon, to do experiment and observation on natural phenomenon, and to understand the natural characteristics and life cycle of animal and plant. Science subject covers life process, environment, material, energy, and astronomy.

e. Sakai(Social Science)

This subject is intended to educate the students to understand the community where they live, relate regional characteristics to their own life, do a research on social problems, understand the development process of national economy and industry, understand national and 
world history, and promote mutual understanding o international cooperation. This subject covers regional economy, local life, national and world history, national trade and industry, international trade and industry, international relationship and so forth.

f. Sogo(General Subject)

This subject is aimed at educating the students to promote their interest and talent, their way of thinking to problem solving, and help the students determine the future goals of life. The subject includes English activity, volunteer activity, literary works, and others.

g. Seikatsu(Social Life)

This subject is intended to promote students' interest on environmental issue and how to conserve it, help the students enjoy the life such as school environment and activity, to make better social relationship and cooperation, to be highly motivated to live.

h. Kateika(Home Making)

This subject is aimed at educating the students to understand family life, find the way to improve family life standard, have knowledge on household activities like, sewing, knitting, cooking, cleaning and so on. This subject includes family life, household management, household activities, etc.

i. Health Education

The goals of this subject are to promote students' understanding on the importance of sport activity for healthy life, to promote students' creativity through sport activity, to promote social relationship and cooperation through sport activity, to have understanding of mental health. This subject includes games, martial arts, athletics, aquatic sport, recreational activities, knowledge about initial treatment of accident, and knowledge of mental health.

j. Ongaku(Music)

This subject is intended to promote students' interest in singing and performing art, and improve students' ability to play musical instruments.

k. Zukoka(Handicraft)

The aim of this subject is to promote students' imagination and creativity through handicraft creation. This subject covers origami, sculpturing, knitting and so on.

\section{English Subject}

National Institute for Educational Research of Tokyo (2002) reports that the implementation of English teaching is much affected by the global trends such as social demand, globalization, economic growth, and the advancement of information and communication technologies. In the 
perspective of social demand, people's mobility both within and between countries is very high and English is a means of communication among them. The current world economy is more integrated at both regional and global area and English is needed to support this global trend. The pressure of economic growth makes all countries around the world give priority to develop human skill and English plays a decisive role in human skill development. The increasing access to and use of information and communication technology force the people improve communication skill in English.

English is the most important foreign language in Japan. Almost 20 million of Japanese people travel abroad every year. Japanese industry and business organization spread all over the world. Japan is also very active to involve in international diplomatic affairs, build global harmony, and improve mutual understanding and international cooperation. Many foreign scientists involve in research activities in many Japanese universities. Thus, English is needed and a dominant foreign language in Japanese society. English is a part of Japanese dynamism.

English is taught to elementary school students in Japan as an element of integrated study. This is included in Sogo or General Subject and formally called English activity. The students study how to use English in the real situation through games, song, and other activities. English activity is to prepare the students' future life with some concerned problems like globalization, the aging society, industrialization, international free trade era, the advancement of science and technology. English activity has the main objectives as follows:

a. To improve communicative competence of the students in English.

b. To communicate with Assistant Language Teacher(Native English Teacher) in order to understand the culture and characteristics of other nation especially English speaking country.

c. To have longer time of English learning in order to have more chance to improve communicative competence.

As monocultural and monolingual country, Japanese people only use Japanese as a means of daily communication(Matsuhata et al,1985). This situation affects the learning motivation of Japanese students to study English more. To overcome this serious problem, Japanese Ministry of Education(Monbukagakusho) decides the program called JET Program or the Japan Exchange and Teaching. It is aimed at improving language education in Japan and enhancing internationalization by helping promote international exchange at the local level and mutual understanding between Japan and other countries. In the case of English teaching activity, JET program hires native English teachers from English speaking countries to give assistance to Japanese Teacher of English(JTE). Native English 
teacher functions as Assistant Language Teacher(ALT). ALT has some duties as follows:

a. To give assistance to JTE to conduct English teaching activity.

b. To design English teaching material(supplement material).

c. To conduct in-service training for JTE.

d. To give assistance to manage club activities especially English club activity.

e. To give language information to JTE.

f. To conduct activities defined by the host institution.

But, Adachi et al(1998) say that there is still a problem with the presence of ALT in Japanese schools. Many ALTs do not have teacher qualification especially teacher qualification of language teaching for young learners. Most of JTE and ALT can not manage team teaching well so it affects the language learning activity. Adachi et al suggest the government to conduct well managed examination to recruit ALT.

\section{E. Analysis and Conclusion}

Japan is consistent and creative to develop her education standard. Japan is flexible to adopt education system of another country but Japan adjusts it to the spirit and cultural background of Japanese society. Japan not only cultivates the mind of Japanese but also nurtures the heart and spirit of Japanese. What happens in Japanese company or Japanese industry reflects the spirit of Japanese education system.

Japanese company recruits the new staff using the system of human based recruitment. It means that Japanese company trains the new staff to be familiar with the rhythm and target of the company, and the new staff has to build solidarity among company members and develop himself to be professional in his new job that may be different from his background of study. Western company always uses position based recruitment to recruit the new staff of the company. It is just related to the technical aspect to recruit the new staff of company. The Western company just finds the staff to operate the machine, to design the public buildings, roads, bridges and so forth.

Remodeling and innovation are the characteristics of Japanese industry. Japan uses the product of foreign industry as a model and develops it as a new industrial product with high technology. This strategy can boost the product of Japanese industry and win the competition of international trading.

Solidarity is the main spirit of Japanese education. Japanese citizens have to support to one another to keep the survival of Japanese society. The priority has to come to the Japanese. When Japanese company recruits new company staff, the priority must be for the Japanese. The immigration 
bureau of Japan does not release working visa for foreigner if the Japanese can do the job. Individual success is less important but team success is more important in Japanese society.

But, too much priority on solidarity and team success gives side effect to the Japanese education and Japanese society to compete with the people of other countries. Many Indians can win the Nobel Prize as an individual success with a minimal support from the institution and the government. However Japanese get enough support from the institution and the government to do the best in academic activities.

Evaluation is the key element of decentralization and autonomy in Japanese education. Japanese Ministry of Education decides that there is no national examination as a standard of graduation for Japanese students from elementary school until secondary education institution. This situation gives latitude to the school to design and implement the curriculum based on the school target and the real situation within the school. The teacher has a room to accelerate and modify the curriculum according to the student background and the real situation within the class. The school itself decides the program and the target of the school and then the school does internal evaluation to improve the achievement of the target.

We can not deny the fact that flexibility gives positive contribution in the development of Japanese education. Japan adopt teaching strategy, teaching material and other aspects of education but Japan adapts any aspects of education from overseas educational institutions to the cultural background and spirit of Japan. And it makes Japan resilient to face the global challenge and high competition in the global era.

Education is intended to help learners achieve their full potential. Education is fundamental to keep the nation survive, build social order and reach economic affluence of the country. Education develops and progresses in line with social, political, and economic dynamism of the country. Education is aimed at cultivating the mind of students and build strong national character of students. Fundamental goal of Japanese education is to develop Japanese children as the whole person. Japanese education concentrates on nurturing the mind, heart and spirit of students. Intelligence is very important in Japanese education, but to be humane and to endure in any situation are more important.

Curriculum is the main element to operate education activity. Japan develops and modifies the curriculum over and over to make education activity in line with social dynamism of the country. The recent curriculum in Japan is basically school based curriculum. The central government delegates the authority to the school to design its own curriculum based on the school characteristics. The school is the expert to know its problems and 
decide its own goals of education. The recent curriculum reform in Japan happens in 1998. A period of integrated study is the core of 1998 curriculum reform in Japan. Integrated study helps the students design their own curriculum geared towards their own future, find their goals of study and take necessary steps, learn at their own pace. English belongs to general education(Sogo) in Japanese elementary school curriculum, and it makes the program management of English subject less effective. Mostly, ALTs do not have teacher qualification of English teaching for young learners. And both JTE and ALT can not cooperate at each other to manage team teaching well.

\section{F. Reference}

Adachi et al, 1998, Perceptions of the JET Programme, Hiroshima, Keisuisha

Amano Ikuo, 1983, Education and Examination in Japan, University of Tokyo Press

Colin Marsh and Paul Morris,1991, Curriculum Development in East Asia, London, Falmer Press

Cook and Doll, 1973, The Elementary School Curriculum, Boston, Allyn\&Bacon,Inc.

Cummings William, 1980, Education and Equality in Japan, New Jersey, Princenton University Press.

Hall and Jones, 1976, Competency-Based Education, New Jersey, PrenticeHall, Inc.

Herbert Passin, 1965, Society and Education in Japan, Tokyo, Kodansha International

James J. Shields, Jr., 1993, Japanese Schooling, The Pennsylvania State University.

Keenleyside and Thomas, 1937, History of Japanese Education, Tokyo, The Hokuseido Press

Koike Ikuo et al, 1978, The Teaching of English in Japan, Tokyo, Eichosha Publishing

Katayama et al, 1985, Readings on Teaching English as a Foreign Language, Tokyo, Daishukan

Okano and Tsuchiya, 1999, Education in Contemporary Japan, Cambridge, Cambridge University Press

Rohlen and Bjork, 1998, Education and Training in Japan, New york, Routledge 
Abdul Aziz -Japanese Education and Japanese Elementary School

Stevenson et al, 1986, Child Development and Education in Japan, New York, W.H. Freeman and Company

Tanner and Tanner, 1980, Curriculum Development, New York, MacMillan Publishing

Trends in Foreign/Second Language Education in Asia and the Pacific, National Institute for Educational Research of Tokyo,2002

www.mext.go.jp 